\title{
EFFECT OF GRAFTING TO IMPROVE SALT TOLERANCE IN CHICKPEA
}

\section{(Cicer arietinum $\mathbf{L})$}

\author{
RICHA CHAUHAN $^{1} \&$ AVNISH CHAUHAN ${ }^{2}$ \\ ${ }^{I}$ Department of Botany, Chaman Lal Mahavidyalaya, Landhaura, Roorkee, Haridwar Distt., UK, India \\ ${ }^{2}$ Department of Environment Science, Graphic Era Hill University, Dehradun, UK, India
}

\begin{abstract}
The influence of sodium chloride salinity on plant growth was studied in seven cultivars of chickpea. With increasing concentration of salinity level have simultaneously progressive absorption of $\mathrm{Na}^{+}$in determinant of $\mathrm{K}^{+}$, thereby increasing $\mathrm{Na}^{+}$and $\mathrm{K}^{+}$interaction causing an ionic disequilibrium which possibly suppressed plant growth. Genotype, K 850 showed maximum germination under $1.71 \mathrm{mMNaCl}$. Genotype CSG 8890 showed maximum reduction in radical as well as plumule length and minimum with Bio 201. Grafting high yielding but saltsusceptible chickpea cultivars onto salt resistant/tolerant root stocks is a sustainable strategy to overcome saline stress. The positive response of grafting exerted by tolerant rootstocks or scion-rootstock interactions on yield and pod characteristics of chickpea under saline conditions is attributed to several physiological and biochemical changes. In this paper, the importance of chickpea grafting, strategies to select appropriate rootstocks, scionrootstock interaction for growth, yield and quality characteristics, as well as the tolerance mechanisms that (grafted) plants deploy to circumvent or minimize the effects of salt stress in root zones are discussed.

KEYWORDS: Salt, NaCl, Na/K Ratio, Plant Growth, Salt Resistant, Salt Susceptible, Cicer Arietinum L. Genotypes , Grafting
\end{abstract}

Received: Jun 08, 2020; Accepted: Jun 28, 2020; Published: Sep 16, 2020; Paper Id.: IJMPERDJUN20201263

\section{INTRODUCTION}

Mostly places of the world, characterized by low-rainfall winters and rainless summers, sodic soils can become salted to different degrees with moderate irrigation. In developing countries, secondary salinization is a severe problem, as they may be responsible for the loss of once productive agricultural land (Chavanand and Karadge, 1986). The magnitude of salt accumulation in the soil is depend on the quality of irrigation water, techniques and quantity of irrigation, quality of soil and rainfall.

Salinity usually inhibits plant growth which can either be due to osmotic dehydration (is an used for the partial removal of water from plant tissues by immersions in a hypertonic solution), certain ion toxicity is usually associated with immoderate chloride and sodium intake and ion imbalance (Bernstein, 1963, Gorham et al, 1985, Cheeseman, 1988 and Judith et al 2017). Plant grown in saline conditions has high content of $\mathrm{Na}^{+}$and $\mathrm{Cl}^{-}$ion imbalance (Bernstein 1963, Gorham et al. 1985, Cheeseman 1988 and Judith et al. 2017). Plants grown in saline condition have high content of $\mathrm{Na}^{+}$and $\mathrm{Cl}^{-}$ion imbalance as well as under saline conditions have low content of $\mathrm{Na}^{+}$ and $\mathrm{Cl}^{-}$ions and low $\mathrm{K}^{+}$content in growing tissues, both conditions affecting the establishment of the balance required for normal metabolic reactions (Bange 1959, Greenway and Munns 1980 and Cusido et al, 1987). Grafting is a horticultural technique whereby tissue of plants are joined so as to continue their growth together (Colla et al. 
$2010 \&$ 2013). The upper part of the combined plant is called the scion while the lower part is called the rootstock. The success of this joining requires that the vascular tissues grow together and such joining is called inosculation. The technique is most commonly used in asexual propagation of commercially grown plants for the horticultural and agricultural trades (Singh et al, 2017 \& Singh et al, 2020). An experiment was showing the grafting effect on salt mixtures in the plant growth of chickpea (Cicer arietinum L.).

\section{MATERIALS AND METHODS}

Seeds of seven chickpea cultivators viz., C235, K 850, BG 256, CSG 8962 Karnal Chana-1, CSG 8890, Bio104 and Bio 201 sown into petridishes layered with whatman filter paper. Four levels of saline water were created to give $0,0.43,0.86$ and $1.71 \mathrm{mM}(20 \mathrm{ml}$ of salt solution) $\mathrm{NaCl}$ into the Petridishes. In control $20 \mathrm{ml}$ distilled water was used the electrical conductivity value of the salt was $4.23,7.36$ and $8.0 \mathrm{ds} / \mathrm{m}$, respectively. Each petridish was used after saturation with $20 \mathrm{ml}$ of salt solution daily after draining out previous solved solution. The whatman filter papers were also replaced after every 2 days. Observations were recorded after every alternate day on germination percentage under different treatments after 15 days of culture.

Fresh plants were dried at $80^{\circ} \mathrm{C}$ for 24 hours. The samples were then gri nd in a blender for sodium and potassium estimation. For the estimation of sodium and potassium $500 \mathrm{mg}$ dry weight of the tissue was digested in $5 \mathrm{ml}$ of tri acid mixture (Concentrated 10, $\mathrm{HNO}_{3}: 4 \mathrm{HClO}_{4}: \mathrm{H}_{2} \mathrm{SO}_{4}$ ) in a corning necked flasks for overnight. Refluxing in digestion block at $180^{\circ} \mathrm{C}$ for 30 minutes resulted in decolouration of the digested solution which was followed by addition of $20-30$ $\mathrm{ml}$ of deionized water. It was filtered by whatman filter paper and sodium and potassium were estimated by flame photometer from the stock solution using $\mathrm{NaCl}$ and $\mathrm{KCl}$ as standard.

The shoot of each genotype was cut from the middle of the second internode starting from soil surface for grafting. Three different procedures were used for preparation of scion and root stock.

- $\quad$ Saddle Grafting

- Whip Tongue grafting (Mid Grafting)

- Side grafting

\section{Saddle Grafting}

Diagonal cuts of equal length were made on the scion and stocks of equal girth in the form of saddle to match each other. These two components were brought together facing cambium layers, tide securely and coated with grafting compounds (aluminium foil, straw pipe and wax)

\section{Whip Tongue Grafting}

The girth of the plants selected were approximately $0.8 \mathrm{~cm}$ in diameter. Diagonal cuts on both scion and root stock were made. Approximately more than $1 \mathrm{~cm}$ long plantlets were chosen for grafting purpose. Long smooth sloping cut was made in scion at one stroke root stock was prepared by making cut in reverse downward direction starting about $1 / 4$ of the distance from the top. The scion and the root stock were interlocked in such a way that the cambium layer matched on both the sides of completed grafts and secured in position with grafting material. 


\section{Side Grafting}

The scion was placed latterly on the side of a root stock. The scion was prepared by removing all the lateral branches and vegetative growths were removed near the point of graft. The long, slopping and wedge shaped cut was made for scion. Soon after bringing together thr root stock and scion, the point of the union was sealed with grafting material.

Three kinds of materials such as straw pipe, aluminium foil and wax were used for assembly of root stock and scion. A direct cut of $0.5 \mathrm{~cm}$ size was made in the root stock. The first leaf on the root stock was removed by blade to facilitate easy slip over a straw pipe/ aluminium foil/wax assembly. The length of straw pipe was selected depending on the length of the root stock. This assembly was slipped down to union point of scion and root stock to provide proper strength. The scion was sliced from both sides, removing the skin of the stalk with the help of blade and the inserted in the cut of the root stock. The straw pipe/aluminium foil was pulled down to the joint while wax was pasted to the joint. The pots were filled with gravel. The planting material for root stock was grown into pot containing sand. The grafted plants in pot containing sand were kept in bigger pot and watered twice a day. The water was also sprayed over the gravel to keep condition humid and cool around the pots. The pots were protected from the direct light by covering from all sides with the black opaque sheets. The sprouts coming up from the nodes of the root stock were removed daily to retain true scion only . After 5 days, the grafted plants were shifted to light conditions. The plants were watered with 1/4 Hoagland solution as per their requirement. After days of grafting, assembly of the straw pipe/aluminium foil/wax was removed by cutting them gently from one side down and the pulling apart the two folds.

\section{RESULTS AND DISCUSSION}

In general, increasing the dose of $\mathrm{NaCl}$ decrease the germination percentage (table 1). The maximum reduction in germination (25\%) was noticed at $1.71 \mathrm{mM} \mathrm{NaCl}$. However, least reduction in germination percentage $(96.36 \%)$ was observed at $0.43 \mathrm{mM} \mathrm{NaCl}$ the salt mixtures having $\mathrm{NaCl}$ and $\mathrm{CaCl}_{2}$ and $\mathrm{MgCl}_{2}$ were used in different ratios as chickpea is reported to be more sensitive to chlorides than sulphates (Manchanda et al 1981 and Manchanda and Sharma, 1989). Among various genotypes used K 850 showed maximum germination (62\%) under $1.71 \mathrm{mM} \mathrm{NaCl}$ is followed by BG256 $(60 \%)$. However high reduction $(25-46.15 \%)$ in germination percentage was noticed for sensitive genotypes CSG 8890 , Bio 104 and Bio 201 (table 1)

The effect of salinity level on seedling vigour is reflected as radicle and plumule length (table 2). There was considerable difference among genotypes in respect of reduction in radicle and plumule length under saline condition. Maximum reduction in radical length $(59.12 \%)$ was noticed with genotype CSG 8890 and minimum with Bio 201 (14.78\%). Besides other genotypes showed moderate reduction in radical length (table 2). Genotype Bio 102 also showed minimum reduction (3.89\%) in plumule length. However, there was a large reduction in plumule length $(24.72 \%-28,0 \%)$ in CSG 8890, CSG 8962 karnal chana 1 and K850 (table 2). The response of genotype to salinity varied significantly irrespective of different concentration of $\mathrm{NaCl}$. All the genotypes showed differential performance to germination percentage, radicle and plumule length. These parameters for effective index for discriminating effect under various treatments and genotypes. However, Dua and Sharma in 1996 advocated that germination is not a good index of salinity tolerance rather survival percentage could be considered as one of the component of salinity tolerance of pigeonpea. Several other reports (Akbar and Yabuno, 1977) also indicated that no correlation existing between tolerance at germination and later growth stages in different crops. Further, it was postulated that survival percentage should be taken as selectively better indicator of genotypes having high yield under salinity (Dua, 1991 and Munns et. al., 2008). 
Varying degree of salinity symptoms were observed under different levels of salinity in salt sensitive and resistant genotypes. These symptoms were intensify on increasing doses of salt. Their symptoms ranged from yellowing, browning, leaf senescence to partial and complete death of the plants. Among various genotypes used, more intensive symptoms were observed in salt sensitive genotypes as compared to salt tolerant genotypes. The results similar to finding of present investigation on initiation and development of symptoms under different levels of salinity has also been reported in various crops viz, wheat (Bhardwaj and Rao, 1960 \& Balasubramanian and Sarin, 1974), cowpea (Balasubramanian and Sarin, 1976), mungbean (Balasubramanian and Sarin, 1976), gram (Bhardwaj and Rao, 1960, Lauter and Munns, 1982 louder and 1986, \& Mamo et al., 1996) Broad bean (Dua et al. 1989) and pea (Dua et al. 1989).

The radicle and plumule length was also found very effective index in discriminating chickpea genotypes under different levels of salinity. The relative reduction in plumule and radicle length may be taken as a more reliable index than germination percentage as these are not easily affected by environmental condition. The results obtained earlier in chickpea (Dua and Sharma, 1996,1997 and Dua 1998 ) are also in agreement with the finding of present investigation.

There were no significant differences among genotypes with regards to $\mathrm{Na}^{+} / \mathrm{K}^{+}$uptake ratio indicating no significant difference in tolerant levels to $\mathrm{NaCl}$.

Since the Survival rate of in vitro derived plantlet in pot under saline condition was very low, grafting procedure were standardized to increase the survival if in vitro derived plantlets, the details of these experiments were depicted in table 4. Out of three grafting methods used, mid grafting method showed maximum (40.50\%) success followed y side grafting (18.07\%). However, minimum success (3.08\%) was achieved while saddle grafting method was used. Out of three method of joining scion and root stock, straw pipe method showed best response (35.85\%) interms of survival of successful grafted plants. Similar results were also found in Solanaceace family (Keatinge et al, 2014).

Table 1: Relative Genotypic Sensitivity under Different Salinity Level in Chickpea

\begin{tabular}{|c|c|c|c|}
\hline \multirow{2}{*}{ Genotype } & \multirow{2}{*}{ Germination (\%) } & $\begin{array}{c}\text { Radicle Length (\%) } \\
\text { Reduction as Against Control }\end{array}$ & Plumule Length (\%) \\
\hline C 235 & 55.56 & 48.61 & 19.44 \\
\hline K 850 & 60.56 & 52.55 & 24.72 \\
\hline BG 256 & 54.53 & 41.26 & 15.83 \\
\hline CSG 8962 Karnal Channa-1 & 69.00 & 55.32 & 27.44 \\
\hline CSG 8890 & 27.75 & 59.12 & 28.00 \\
\hline Bio 104 & 30.78 & 46.96 & 13.89 \\
\hline Bio 201 & 44.44 & 14.78 & 03.89 \\
\hline
\end{tabular}

Table 2: Survival (\%) of Explant Under Different NaCl Concentration

\begin{tabular}{|c|c|c|c|c|}
\hline \multirow{2}{*}{ Genotype } & \multicolumn{4}{|c|}{ NaCl Concentration } \\
\cline { 2 - 5 } & Control (\%) & $\mathbf{0 . 2 5 \%}$ & $\mathbf{0 . 5 \%}$ & $\mathbf{1 . 0 \%}$ \\
\hline C 235 & 100 & 90.90 & 80.00 & 54.39 \\
\hline K 850 & 100 & 96.36 & 86.36 & 62.00 \\
\hline BG 256 & 100 & 96.36 & 74.55 & 60.00 \\
\hline CSG 8962 Karnal Chana-1 & 100 & 100.0 & 61.82 & 54.54 \\
\hline CSG 8890 & 100 & 88.33 & 61.67 & 25.00 \\
\hline Bio 104 & 100 & 88.33 & 35.00 & 25.00 \\
\hline Bio 201 & 100 & 88.33 & 63.63 & 46.15 \\
\hline
\end{tabular}


Table 3: $\mathrm{Na}^{+} / \mathrm{K}^{+}$Uptake of Different Genotypes

\begin{tabular}{|c|c|c|c|c|}
\hline Genotype & Ratio & Uptake of $\mathrm{Na}^{+}(\mathrm{ppm})$ & Uptake of $\mathbf{K}^{+}(\mathrm{ppm})$ & $\mathrm{K}^{+} / \mathrm{Na}^{+}$ratio $+\mathrm{SE}$ \\
\hline \multicolumn{5}{|l|}{ CSG 8962 Karnal chana-1 } \\
\hline $1.0 .5 \% \mathrm{NaCl}$ & - & 0.97 & 0.12 & $0.12 \pm 0.01$ \\
\hline 2.0.5\% NaCl:CaCl${ }_{2}$ & $1: 1$ & 0.69 & 0.11 & $0.16+0.02$ \\
\hline 3.0.5\% $\mathrm{NaCl}: \mathrm{CaCl}_{2}: \mathrm{MgCl}_{2}$ & $5: 3: 1$ & 0.70 & 0.12 & $0.17 \pm 0.04$ \\
\hline \multicolumn{5}{|l|}{ CSG 8890} \\
\hline $1.0 .5 \% \mathrm{NaCl}$ & - & 1.45 & 0.13 & $0.09 \pm 0.02$ \\
\hline $2.0 .5 \% \mathrm{NaCl}: \mathrm{CaCl}_{2}$ & $1: 1$ & 1.18 & 0.14 & $0.12 \pm 0.04$ \\
\hline $3.0 .5 \% \mathrm{NaCl}: \mathrm{CaCl}_{2}: \mathrm{MgCl}_{2}$ & $5: 3: 1$ & 0.43 & 0.12 & $0.19 \pm 0.03$ \\
\hline \multicolumn{5}{|l|}{ Bio 104} \\
\hline $1.0 .5 \% \mathrm{NaCl}$ & - & 1.17 & 0.12 & $0.10 \pm 0.07$ \\
\hline $2.0 .5 \% \mathrm{NaCl}: \mathrm{CaCl}_{2}$ & $1: 1$ & 1.60 & 0.17 & $0.11 \pm 0.05$ \\
\hline 3.0.5\% NaCl:CaCl$: \mathrm{MgCl}_{2}$ & $5: 3: 1$ & 0.53 & 0.10 & $0.19 \pm 0.04$ \\
\hline
\end{tabular}

Table 4: Comparison of Different Grafting Method in Chickpea

\begin{tabular}{|c|l|c|c|c|c|}
\hline S. No. & Method of Grafting & \multicolumn{3}{|c|}{ Method of Joining } & Total (\%) \\
\hline & & Aluminium Foil & Wax & Straw Pipe & \\
\hline 1. & Side Grafting & 00 & 00 & 15 & $18.07 \%$ \\
\hline 2. & Mid Grafting & 00 & 04 & 78 & $40.59 \%$ \\
\hline 3. & Saddle Grafting & 00 & 00 & 02 & $03.08 \%$ \\
\hline & Total & 00 & 10.00 & 35.85 & \\
\hline
\end{tabular}

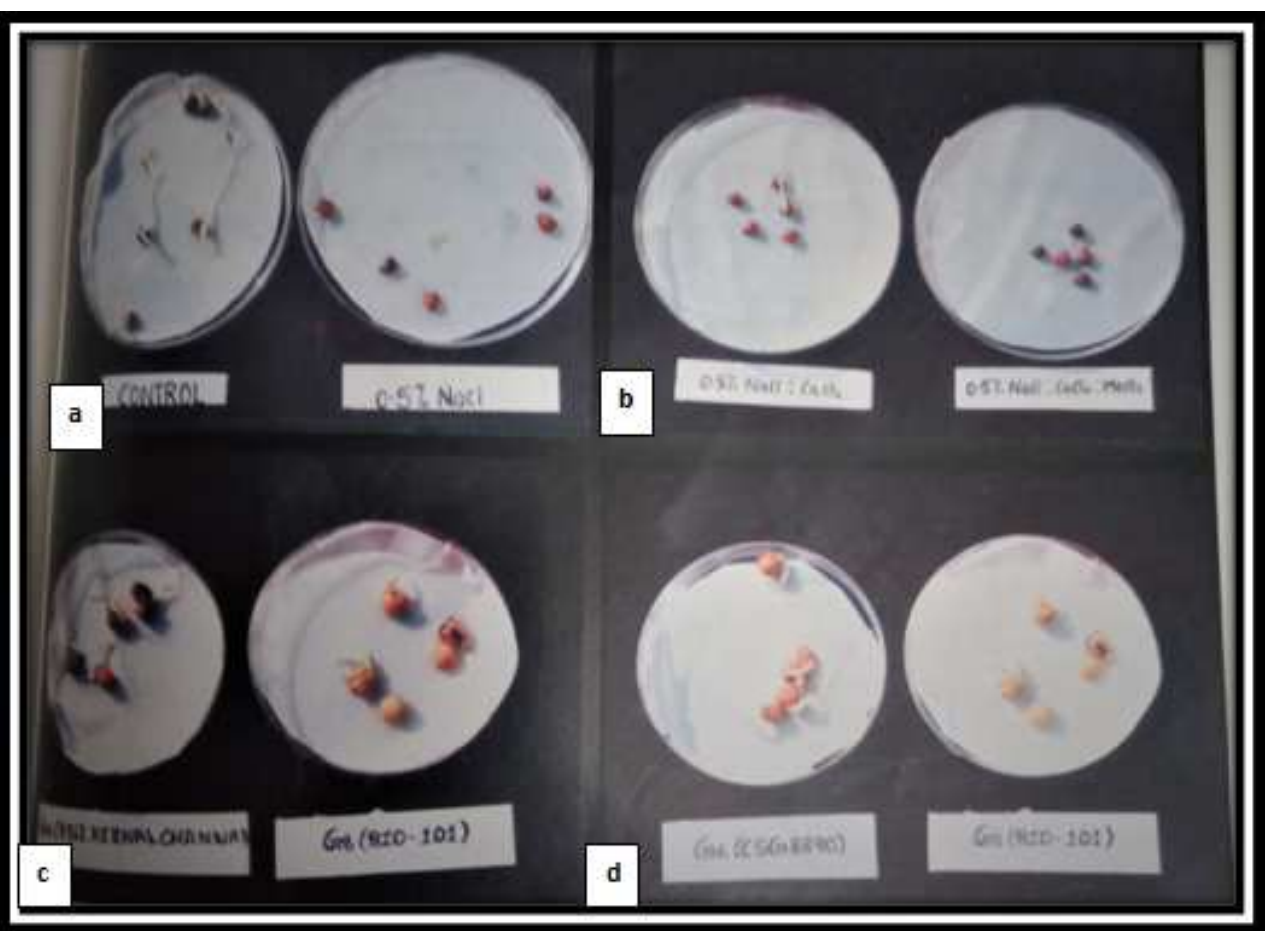

Figure 1: Effect of Salt and Salt Mixtures on Seedling Emergence of Chickpea Genotypes.

- Difference between control and $0.5 \% \mathrm{NaCl}$

- Difference between $0.5 \% \mathrm{NaCl}: \mathrm{CaCl}_{2}$ : and $0.5 \% \mathrm{NaCl}: \mathrm{CaCl}_{2}: \mathrm{MgCl}_{2}$

- Difference between tolerant and test genotypes

- Difference between tolerant and test genotypes 


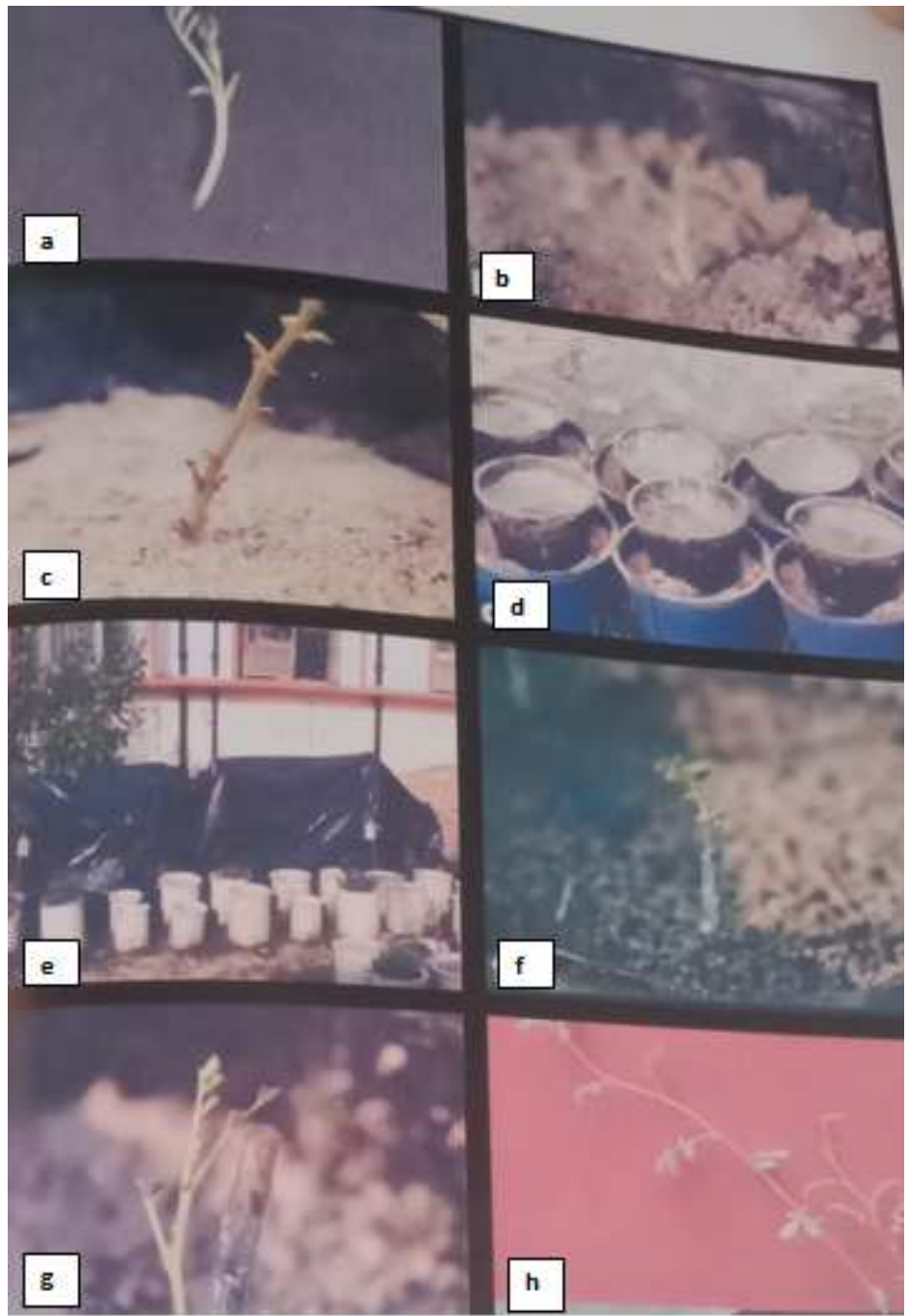

Figure 2: Grafting of Root Stock and Scion of Different Genotypes of Chickpea.

- Preparation of the scion

- Preparation of the root stock

- Union of scion and root stock using straw pipe

- Conditioning of grafted plants

- Grafted plant showing successful union of root stock and scion

- Failure of grafting showing wilting and drying on grafted portion

- Successfully growing of grafted plants showing stems with simple leaf of mother plant and normal leaf of grafted plant 


\section{REFERENCE}

1. Akbar M and Yaburo T (1977). Breeding for saline resistance varities of rice. IV Inheritance of delayed type panicle sterility induced by salinity. Japan J. Breeding: $27: 237-240$.

2. Balsubramanian V. and Sarin MN (1974), An analysis of growth of salt stresses wheat seedlings. Indian Journa of Plant Physiology. $16: 22-27$.

3. Mayuri Banerjee Bhattacharya, S. C. Upaddhay\& Arvind Kurmar , "Socio Economic and Nutritional Status in 'Agariyas': Salt Cultivators' Work as Contractual Manpower in Organized Salt Industries “, International Journal of Applied and Natural Sciences (IJANS), Vol. 7, Issue 6, pp. 69-84

4. Balsubramanian V. and Sinha SK (1976). Effects on salt stress on growth, nodulation and nitrogen fixation in cowpea and mungbean. Physiology Plantarum 36:197-200.

5. Bange GGJ (1959). Interactions in the potassium and sodium absorption by intact maize seedlings. Plant and Soil 11: 17-29.

6. Bernstein L (1963). Osmotic adjustment of plants to saline media. II dynamic phase. American Journal of Botany 48: 909 918.

7. Bhardwaj SN and Rao IM (1960). Physiological studies on salt tolerance in crop plants. IX Effect of NaCl and Na2CO3 on seedling respiration and growth of wheat and gram. Indian Journal of Plant Physiology 3:56-71.

8. Colla G., Rouphael Y., Leonardi C. and Bie, Z (2010). Role of grafting in vegetable crops grown under saline conditions. Sci. Hortic. , 127, 147-155. [CrossRef]

9. Colla G., Rouphael Y., Jawad R., Kumar P., Rea E. and Cardarelli M. (2013). The effectiveness of grafting to improve NaCl and CaCl2 tolerance in cucumber. Sci. Hortic. 164, 380-391. [CrossRef]

10. Chavan PD and Karadge BA (1986). Growth, mineral nutrition, organic constituents and rate of photosynthesis in Sesbania grandiflora L. grown under saline conditions Plant and Soil 93: 395-404.

11. Cheeseman JM (1988). Mechanism of salinity tolerance in plants. Plant Physiology 87: 547-550.

12. Cusido RM, Plazon J, Altabella T and Morales C (1987). Effect of salinity on soluble protein, free amino acids and nicotine contents of Nicotiana rustica L. Plant and Soil 102: 56-60.

13. Dua RP, Sharma SK and Mishra B (1989). Response of broad bean (Vicia faba) and pea (Pisum sativum) varieties to salinity. Indian Journal of Agricultural Sciences 59:729-731.

14. Dua RP (1991). Differential response of chickpea (Cicer arietinum L.) genotypes of salinity. Indian Journal of Agricultural Sciences (Cambridge) 119:367-71.

15. Dua RP and Sharma SK (1997). Suitable genotypes of gram (Cicer arietinum L.) and mechanism of their tolerance to salinity . Indian Journal of Agricultural Sciences. 67: 102-106.

16. Dua RP (1998). Salinity tolerance in chickpea. Indian Journal of Plant Physiology 3:102-106.

17. Gorham J, Wyn Jones RG and McDonnell E (1985). Some mechanism of salt tolerance in crop plants. Plant and Soil 89: 1540 .

18. M. R. Tailor, “Approaches to Modeling Unstable Flow and Mixing of Variable of Density Fluids “, BEST: International Journal of Humanities, Arts, Medicine and Sciences (BEST: IJHAMS), Vol. 4, Issue 1, pp. 49-60

19. Greenway $H$ and Munns $R$ (1980). Mechanism of salt tolerance in non-halophytes. Annual Review of Plant Physiology 31:149-190. 
20. Judith Atieno, Yongle Li, Peter Langridge, Kate Dowling, Chris Brien, Bettina Berger, Rajeev K. Varshney and Tim Sutton (2017). Exploring genetic variation for salinity tolerance in chickpea using image-based phenotyping Published online 2017 May 2. doi: 10.1038/s41598-017-01211-7

21. Keatinge J.D.H., Lin L.J., Ebert A.W., Chen W.Y., Hughes J.A., Luther G.C., Wang J.F. and Ravishankar M. (2014). Overcoming biotic and abiotic stresses in the Solanaceae through grafting: Current status and future perspectives. Biol. Agric. Hortic. 30, 272-287. [CrossRef]

22. Lauter DJ and Munns DW (1982). Salt response of chickpea and cowpea genotypes to different ionic composition. Agron. Abs. 213.

23. Lauter DJ and Munns DW (1996). Salt tolerance of chickpea during vegetative growth and at different humidity. Australian Journal of Plant Physiology 14: 171-180.

24. Mamo T, Richtes $C$ and Heigtag B (1996). Salinity effects on growth and ion content of chickpea (C. arietinum L) and Lentil (Lens culnaris medic.) varieties. Journal of Agronomyb and Crop Sciences 176: 235-247.

25. Manchanda HR, Sharma SK, Dixit ML, and Singh S (1981). Possibility of growing chickpea in chloride and sulphate dominant saline conditions. In all India Seminar on Water Resources- Its Developments and Management, Chandigarh, India . PP: 1930 .

26. Manchanda HR and Sharma SK (1989). Tolerance of chloride and sulphate salinity in chickpea. Journal of Agricultural Sciences 113: 407-410.

27. Munns R and Tester M. (2008). Mechanisms of salinity tolerance. Vol. 59:651-681. [PubMed] [Google Scholar]

28. Sadhna Chaturvedi, Tejovathi Gudipati \& Archna Shrivastav, "Analysis of Proline and MDA and Protein Profile in Seedlings of Cowpea Exposed to NaCl Salinity - Influence of Rhizobacterium on Salt Tolerance”, International Journal of Applied and Natural Sciences (IJANS), Vol. 6, Issue 4, pp. 97-106

29. Atulkumar H. Patel, "Electrical Conductivity in Relation with Macro-Micro Nutrients of Agricultural Soil of Amreli District “, BEST: International Journal of Humanities, Arts, Medicine and Sciences (BEST: IJHAMS), Vol. 3, Issue 8, pp. 25-30

30. Singh H., Kumar P., Chaudhari S. and Edelstein M. (2017). Tomato grafting: A Global perspective. HortScience , 52, 13281336. [CrossRef]

31. Singh H., Kumar P., Kumar A., Kyriacou M.C., Colla G. and Rouphael Y. (2020). Grafting Tomato as a Tool to Improve Salt Tolerance. Agronomy 10: 1-22 ; (www.mdpi.com/journal/agronomy). 